\title{
Physical, Mechanical and Hygrothermal Properties of Lateritic Building Stones (LBS) from Burkina Faso
}

\author{
A. Holur Narayanaswamy ${ }^{1}$, F. McGregor ${ }^{1}$, Y. Millogo $^{2,3}$ A. Fabbri $^{1}$, A. D. Séré ${ }^{2}$, \\ J.E Aubert ${ }^{4}$, J.C. Morel ${ }^{5}$ \\ ${ }^{1}$ Université de Lyon/ENTPE/LGCB-LTDS (UMR CNRS 5513) Vaulx-en-Velin 69120, France \\ ${ }^{2}$ Unité de Formation et de Recherche en Sciences et Techniques (UFR/ST), Université Polytechnique de Bobo- \\ Dioulasso, 01 BP 1091 Bobo 01, Burkina Faso \\ ${ }^{3}$ Laboratoire de Chimie Moléculaire et des Matériaux (LCMM), UFR/ Sciences Exactes et Appliquées, Université de \\ Ouagadougou, 03 B.P. 7021 Ouagadougou 03, Burkina Faso \\ ${ }^{4}$ Laboratoire Matériaux et Durabilité des Constructions (LMDC) Université Paul Sabatier - INSA Génie Civil \\ 31077 Toulouse, France \\ ${ }^{5}$ Centre for Low Impact Buildings, School of Engineering, Environment and Energy, University of Coventry, RU
}

\section{$\underline{\text { Abstract }}$}

Earth is a predominant eco-friendly construction material which provides a good occupational comfort consuming less energy. To improve the durability performance, stabilization is commonly adopted. However the additional costs induced by such process cannot be afforded by the majority of the population in developing countries, and in some circumstances, the environmental side effect may be controversial. Alternatively, laterite stone which is natural available and readily stabilized material that can be used for building construction is studied in this paper. Lateritic building stones (LBS) from Burkina-Faso are studied for their hygroscopic, physical and mechanical characteristics by conducting experimental investigation such as moisture sorption and desorption, moisture buffering, three-point bending, and cyclic unconfined compression test. The analysis is focused on the moisture ingress of the material and its impact on the mechanical strength and also an insight on understanding linear elastic behaviour of LBS 
is carried out. The experimental results are compared with the stabilized and un-stabilized earthen construction materials. This comparison underlines the good performances of LBS, in both mechanical and hygrothermal properties as a building material.

Keywords: Lateritic building stones, Physical, Mechanical and Hygrothermal Characteristics, Building Materials, Burkina Faso

\section{Introduction}

With ever growing construction industry, the concern of the environmental aspect is also growing $[1,2]$. Because main stream construction materials contribute huge junk to global pollution, the need to promote locally available renewable and sustainable building materials is taking centre stage. Research work on exploring engineering properties of the alternative building material is ongoing. Use of compressed earth block (CEB), rammed earth, adobe, etc., are being considered as the strong alternatives [3-8]. Actually, earthen material needs few or no transformation to be used as a construction material and it can be directly extracted close to the construction site. Moreover, the affinity of raw earth for water molecules brings a well-known quality for interior comfort, both acoustic, hygric and thermal [9-12]. The water in the wall is also responsible of its complexity in mechanical behaviour: water retention contributes to the cohesion of the material, but too important water content leads to a strong decrease in mechanical resistance and can lead to collapse [13]. A way to enhance the mechanical performance of earthbased materials, and in particular to limit the impact of water content, is to use mineral stabilizers

like lime and cement $[14,15]$. However, the environmental side-effects of stabilized earth are sometimes controversial [16-18] and the additional costs induced by such process cannot be afforded by the majority of the population in developing countries.

In this context, the use of LBS, which is a sustainable alternative has not been given due importance in terms of its mechanical capabilities. The laterite deposits which are abundantly available in tropical countries [19][20], is rich in aluminium, silica and iron oxides, varies with mineral and chemical composition based on formation [21]. The mineralogy and natural 
chemical stabilization due to weathering makes this porous material sufficiently strong, thus it is cut and used as building blocks. The term laterite was first coined by Buchanan in 1807 [20], then it was used as replacement for bricks in Malabar region, India.

Thanks to its natural inherent property, making way to be potential alternative building material. Due to lack of sufficient scientific data, confidence level in using it as an alternative building material is decreasing [22]. Variation in mineral and chemical composition due to different exposure makes it even more important to have scientific knowledge about the material property to propose a standardized procedure.

Mechanical parameters such as compressive strength, flexural strength were studied by the active researchers in India and Africa. From studies [23-26], variation of strength with location and strata were observed, and also variation of strength in dry and saturated condition was reported. Due to climate condition in tropical countries, and laterite being porous medium, material response to moisture buffering condition and its influence on mechanical parameters need to be given due importance. Mechanical and hygrothermal parameters are critical in promoting laterite stone as a sustainable alternative, and lack of scientific data promoted this study. In this paper, the LBS from Burkina-Faso is tested and analysed for its response to moisture buffering by studying sorption and desorption, dynamic moisture buffering, and mechanical characteristics such as flexural strength, compressive strength and modulus of elasticity.

\section{Materials and methods}

\subsection{Description of the tested material}

The quarry of studied LBS is situated in Toussiana, located at $10^{\circ} 50^{\prime} \mathrm{N}, 4^{\circ} 37^{\prime} \mathrm{W}$ in the province of Houet, West of Burkina Faso, geographical map is show in $\quad$ Figure 1. Use of locally available LBS proves economical due to its low cost benefit and better thermal comfort, in surrounding locality the LBS are mainly used for building houses, churches, schools, etc. Lateritic stone blocks of dimension $240 \times 120 \times 120 \mathrm{~mm}$ transported from the quarry are tested for its properties, the dry density of the material was found to be $1.85 \mathrm{~g} / \mathrm{cm}^{3}$ with $23 \%$ porosity and the thermal conductivity at $23^{\circ} \mathrm{C}$ and $50 \% \mathrm{RH}$ was found to be $0.96 \mathrm{~W} /(\mathrm{m} . \mathrm{K})$ from ' $\mathrm{FP} 2 \mathrm{C}$ ' hot 
wire apparatus manufactured by NEOTIM. The dry density of the other alternative building materials such as CEB, unstabilised rammed earth and bulk density of adobe, reported from earlier studies are in between $1.5-2.2 \mathrm{~g} / \mathrm{cm}^{3}[27,28], 1.8-2.2 \mathrm{~g} / \mathrm{cm}^{3}$ [29-32] and $1.3-2.2 \mathrm{~g} / \mathrm{cm}^{3}$ [8,33-35] respectively depending on the manufacturing water content and compaction energy adopted while manufacturing. Building houses with locally available materials, such as adobe, $\mathrm{CEB}$, rammed earth, stone are proven to be economical by decreasing processing and transportation cost and at the same time they are also proven to be eco-friendly by reducing embodied energy [4]. LBS are abundantly available in tropical countries, where low cost and sustainable construction is the key for development. LBS with similar basic properties as of adobe, $\mathrm{CEB}$, rammed earth, stone, can be looked as a potential alternative building material which provides economical and eco-friendly solution.

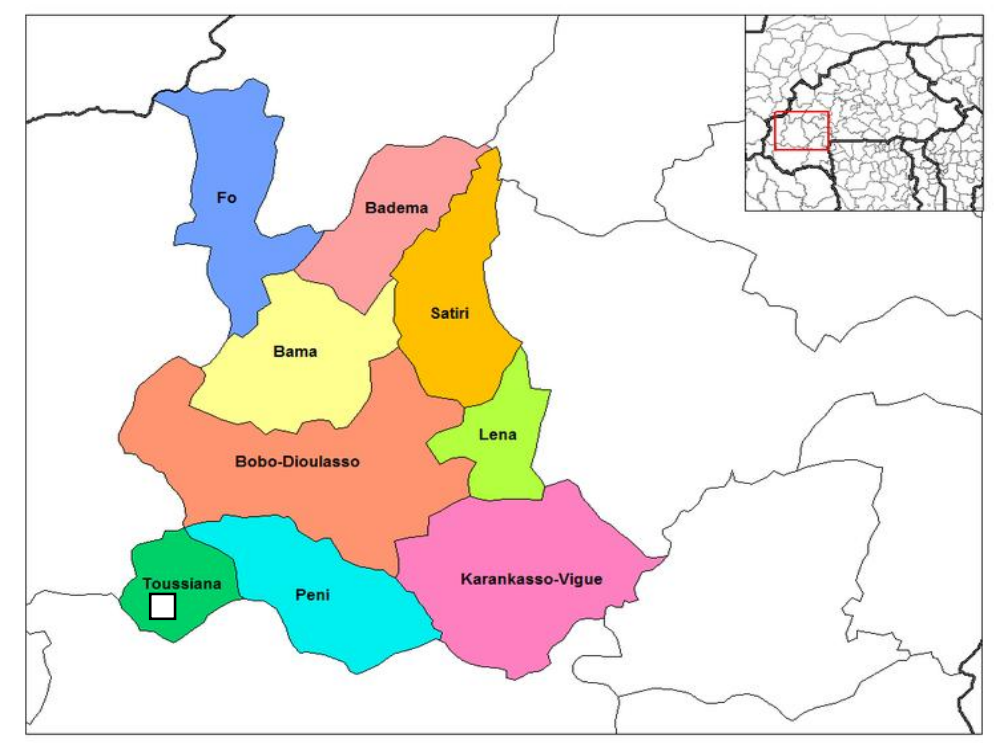

Figure 1: Location of Toussiana in the province of Houet in Burkina- Faso

\subsubsection{Chemical and mineral composition of LBS}

The chemical composition of the lateritic stone block was estimated on digested crushed sample of size $<80 \mu \mathrm{m}$ by Inductively Coupled Plasma - Atomic Emission Spectrometry (ICP-AES). The loss on ignition was evaluated by sample calcination up to $1000^{\circ} \mathrm{C}$. 
X-ray diffraction was used to study the mineralogical composition of the raw material. The X-ray diffraction apparatus used was a Siemens D5000 power X-ray Diffractometer equipped with a monochromator using a $\mathrm{K} \alpha(\lambda=1.789 \AA)$ cobalt anticathode.

The chemical composition of the soil is presented in Table 1

Table 1 Chemical composition of soil

\begin{tabular}{ccccccccccccc}
\hline Oxides & $\mathrm{SiO}_{2}$ & $\mathrm{Al}_{2} \mathrm{O}_{3}$ & $\mathrm{Fe}_{2} \mathrm{O}_{3}$ & $\mathrm{MgO}$ & $\mathrm{CaO}$ & $\mathrm{P}_{2} \mathrm{O}_{5}$ & $\mathrm{MnO}$ & $\mathrm{Na}_{2} \mathrm{O}$ & $\mathrm{K}_{2} \mathrm{O}$ & $\mathrm{TiO}_{2}$ & LOI $^{*}$ & Total \\
\hline Wt.\% & 47.43 & 18.90 & 22.26 & 0.05 & 0.04 & - & 0.01 & 0.01 & 0.05 & 0.70 & 10.34 & 99.79
\end{tabular}

* Loss on ignition at $1000^{\circ} \mathrm{C}$

The sample under study was mainly composed of silica, alumina and iron oxide. Taking into account these above results, it could be concluded that this sample was rich in kaolinite, quartz and iron minerals.

The X-ray diffraction spectrum of the raw material (Figure 2) confirmed that it contained kaolinite $\left(\mathrm{Al}_{2}\left(\mathrm{Si}_{2} \mathrm{O}_{5}\right)(\mathrm{OH})_{4}\right)$, quartz $\left(\mathrm{SiO}_{2}\right)$ and goethite $(\mathrm{FeOOH})$.

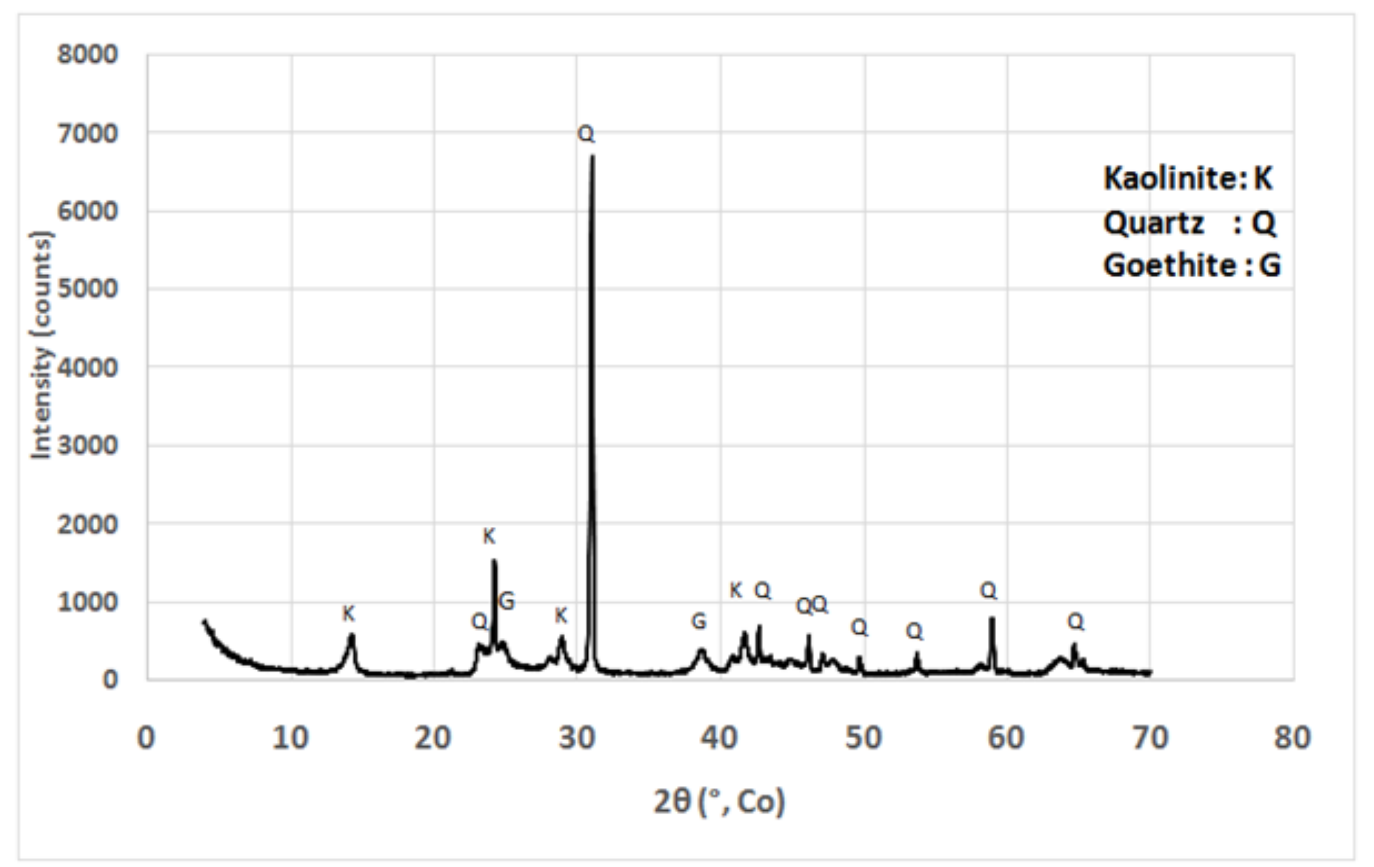

Figure 2: X-ray diffraction pattern of the LBS

The mineralogical composition of the lateritic stone block was obtained by using the mineralogical composition by X-ray diffraction and the chemical composition of the sample. The 
sample studied in this paper contained $47.8 \mathrm{wt}$. $\%$ of kaolinite, $25.1 \mathrm{wt} . \%$ of quartz and $24.8 \mathrm{wt} . \%$ of goethite.

\subsection{Procedure and sample conditioning for the hydric tests}

\subsubsection{Sorption isotherms}

The sorption isotherms were measured to describe the hygroscopic behaviour of the material. The sorption isotherms indicate the moisture content adsorbed by the material to reach equilibrium with the vapour pressure of the surrounding environment. Sorption and desorption isotherms were measured according to the ISO standard [36]. Airtight containers were used with saturated salt solutions to set imposed relative humidity (RH) levels. All samples were previously oven dried at $105^{\circ} \mathrm{C}$ to constant mass (varying in between $25 \mathrm{~g}$ to $50 \mathrm{~g}$ ) before placing them successively in RH levels of 23, 43, 59, 75, 85 and 97\%. The airtight containers were placed in a conditioning room at $20^{\circ} \mathrm{C}$ and $60 \% \mathrm{RH}$. Scales with a precision of $0.01 \mathrm{~g}$ were used to record the mass variation of the samples. The mass was recorded until the variation was less than $0.02 \mathrm{~g}$ between two measurements. Before starting the desorption curve the samples were humidified at 97\% RH until stabilization and then placed in different RH levels. A repetition of three samples per RH was realized to minimize variance of the results due to random error.

\subsubsection{Dynamic vapour sorption-desorption test}

The moisture buffering test was used to investigate the dynamics of moisture adsorption when the material is exposed to a change in vapour pressure from the surrounding environment. With a high buffering capacity, the material may have a positive influence to stabilize fluctuations in the internal environment of dwellings. Such behaviour is commonly allocated to hygroscopic porous building materials such as raw earth and also bio-based materials. The moisture buffering test consists of exposing a known surface of the sample to fluctuating RH levels under isothermal conditions. Small samples of $120 \mathrm{~mm}$ x $60 \mathrm{~mm}$ with a thickness of $60 \mathrm{~mm}$ were sealed with aluminium tape on all faces, only the top face was left exposed. The procedure of the Nordtest was followed [37], the samples were exposed during $8 \mathrm{~h}$ to a $\mathrm{RH}$ of $75 \%$ then during $16 \mathrm{~h}$ to $\mathrm{RH}$ of $33 \%$ at $23^{\circ} \mathrm{C}$. The moisture buffering value (MBV) practical (1) could be calculated from stable cycles. 


$$
M B V_{\text {practical }}=\frac{\Delta m}{A \cdot \Delta R H} \quad \text { Equation } 1 .
$$

Depending on the nature of the material, stable cycles are reached more or less rapidly, those occur when the variation between initial and final mass in between cycles does not vary by more than 5\%. In this case the stabilization occurred rapidly after 4 to 5 cycles. The samples were preconditioned at $50 \% \mathrm{RH}$ and $23{ }^{\circ} \mathrm{C}$.

\subsection{Procedure and experimental protocols of the mechanical tests}

\subsubsection{Sample conditioning}

Lateritic stones are cut into seven small beams of dimension $240 \mathrm{~mm} \times 60 \mathrm{~mm} \times 60 \mathrm{~mm}(\mathrm{~L} \times \mathrm{b} \times \mathrm{d})$. Two of these beams designated as $\mathrm{N} 1$ and $\mathrm{N} 2$ were stored at $25^{\circ} \mathrm{C}$ and $50 \%$ relative humidity in a climate controlled chamber until the moisture equilibrium is attained. The average moisture content of $\mathrm{N} 1$ and $\mathrm{N} 2$ during the test was found to be around 2\%. Two other beams designated as $\mathrm{D} 1$ and $\mathrm{D} 2$ were stored at $100-105^{\circ} \mathrm{C}$ for obtaining oven dry state. The remaining two designated as W1 and W2 were moisten by spraying known quantity of water and wrapped air tight before storing in the climatic chamber at $25^{\circ} \mathrm{C}$. The moisture content of $\mathrm{W} 1$ and $\mathrm{W} 2$ during the test was found to be around $4 \%$.

From the specimens tested for the flexural strength, largest rectangular shaped part is recovered and dressed to fulfil the aspect ratio; such that dimension of the test specimen is $120 \mathrm{~mm} \times 60 \mathrm{~mm} \times 60 \mathrm{~mm}(\mathrm{~h} \times \mathrm{l} \times \mathrm{b})$. Samples tested for compressive strength are stored and conditioned in similar conditions as described for flexural beam specimens. 


\subsubsection{Three point bending test}

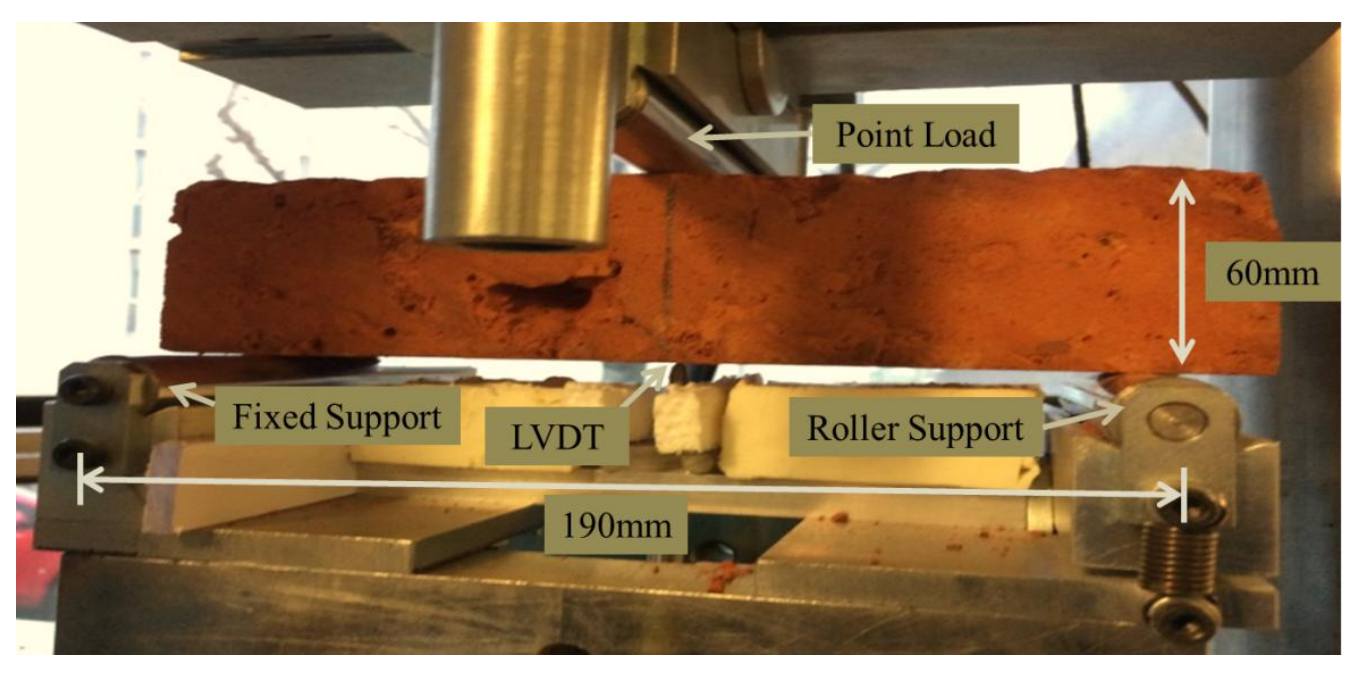

Figure 3 : Three Point Bending Test set up

Customized three point loading system is positioned on the uniaxial compressive testing frame. The base frame of the three point loading system has two adjustable supports (roller support at one end and hinge at the other end). Lateritic specimen of length $240 \mathrm{~mm}$ is positioned on the supports with span of $190 \mathrm{~mm}$. Figure 3 shows the three point bending test setup for lateritic beam specimens. Beam displacement is measured using LVDT, which is placed below the point load where the maximum deflection occurs due to bending. Specimens in bending test are programmed to load at $5 \mu \mathrm{m} / \mathrm{s}$ displacement controlled rate. Due to limited quantity of Lateritic stone blocks, flexural test are planned for three moisture content. Lime paste was used to prepare an even and smooth surface at LVDT point of contact. 


\subsubsection{Unconfined Compressive Test}

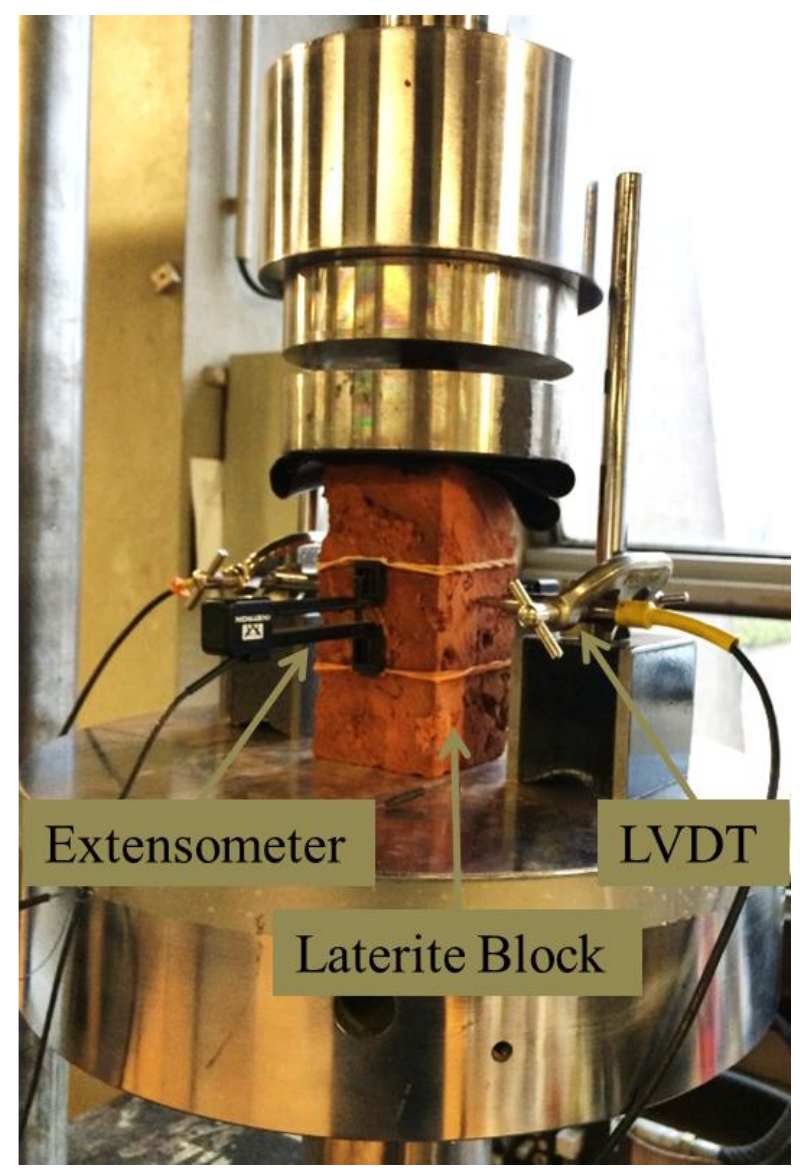

Figure 4 Compression Test Setup

In this study, it was decided to carry out unconfined compression test on the LBS because it gives the most accurate strength of the material [28,38,39]. The unconfined compression test setup of LBS specimen is shown in Figure 4. The compression test was programmed such that, the LBS specimens are subjected to repetitive cyclic loading at a loading cell controlled displacement rate of $5 \mu \mathrm{m} / \mathrm{s}$. The axial strain and lateral displacement of the specimen is measured using $22.5 \mathrm{~mm}$ long extensometer and $\pm 2.56 \mathrm{~mm}$ long LVDT respectively. Considering potential heterogeneity of material, two extensometers are mounted on the opposite face of the specimen. Data from both the extensometers are analysed for any discrepancy. If the strains measured by both the extensometers are in accordance with each other, the average strain of two extensometer is taken as axial strain material as undergone. To avoid platen effect, extensometers are position at the $1 / 3^{\text {rd }}$ height of the specimen. On the other two opposite faces, LVDT's are positioned at mid height of the specimen to measure the lateral displacement. Due to uneven surface, measurements 
of the LVDT's are not precise, hence the data of the lateral displacements are not presented in this analysis.

The elastic behaviour of the LBS is studied by subjecting the specimens to cyclic loading at 5 pre-defined loads. To establish pre-defined loads, a laterite specimen with similar dimension was subjected to simple compressive test without cyclic loading at a controlled displacement rate of $20 \mu \mathrm{m} / \mathrm{s}$. The compressive strength at the failure of the material under compression was found to be $1.5 \mathrm{MPa}$. Considering $1.5 \mathrm{MPa}$ as the material failure compressive stress, pre-defined loads at $20 \%(0.3 \mathrm{MPa} / 1.08 \mathrm{kN}), \quad 30 \%(0.45 \mathrm{MPa} / 1.62 \mathrm{kN}), \quad 50 \%(0.75 \mathrm{MPa} / 2.72 \mathrm{kN})$ and $70 \%$ $(1.05 \mathrm{MPa} / 3.78 \mathrm{kN})$ of the failure compressive stress were chosen for cycles 2 to 5 . While the first pre-defined load $0.1 \mathrm{MPa}(0.36 \mathrm{kN})$ was restricted to the lowest possible stress the loading press can unload and reload without losing contact with the specimen.

For each pre-defined load $(0.36 \mathrm{kN}, 1.08 \mathrm{kN}, 1.62 \mathrm{kN}, 2.72 \mathrm{kN}$ and $3.78 \mathrm{kN})$, three repetitions of loading and unloading were followed before scaling up to the next pre-defined load. Only during the first cycle, the specimen was unloaded to $0 \mathrm{kN}$ this is to ensure that the LBS at very low stress completely regain strain undergone. From second pre-defined load (cycle 2), specimens were loaded until the defined maximum load for each cycle and unloaded until $0.36 \mathrm{kN}$, this was repeated for each cycle. At the end of third repetition for cycle 5, test was programmed such that the specimen is loaded until failure.

\section{Hydric characterization}

\subsection{Sorption-desorption isotherms}

The experimental results of the measured mass variation are shown in Figure 5 as the moisture equilibrium points for the adsorption and the desorption curve. The difference between adsorption and desorption curves is the hysteresis loop. The International Union of Pure and Applied Chemistry (IUPAC) describe four types of hysteresis loops H1, H2, H3 and H4. The hysteresis loop observed for the lateritic stones is of H3 type. In Rouquerol et al. [40] the H3 type hysteresis loop is described as resulting from aggregates of platy particles or adsorbents containing slit-shaped pores. 
The error bars represented in Figure 5 represents the variation within at least 3 samples measured per RH. It is common to have greater uncertainty at higher humidity levels as seen in this case.

In Figure 5, the sorption isotherm of the Lateritic samples is compared with a soil used as unstabilised rammed earth (St Antoine) and a Stabilized Rammed Earth (SRE). The data for the SRE sample was taken from Hall and Allinson [41], the desorption data was ignored as only a very small hysteresis could be observed. The 433 mix corresponds to a SRE mix containing 4 volumes of gravels, 3 volumes of sand and 3 volumes of silty clay. The sorption isotherms of the lateritic material show strong adsorption capacity compared with the rammed earth materials, see Figure 5.

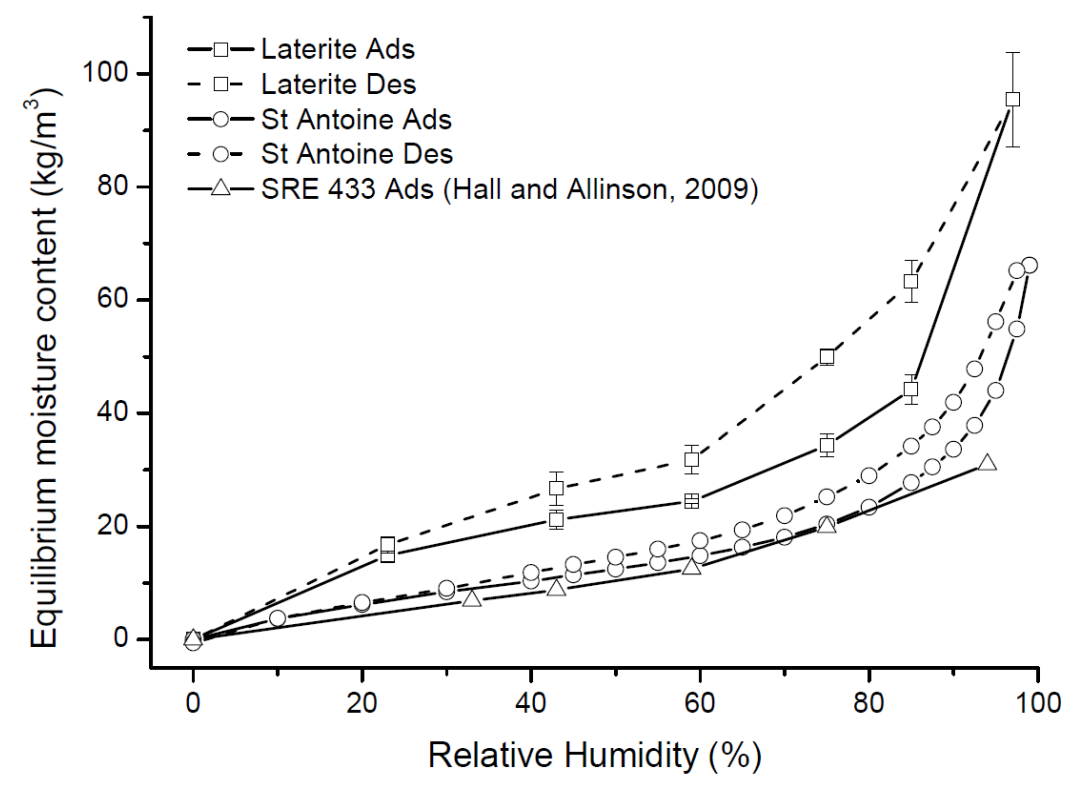

Figure 5 : Adsorption (Ads) and Desorption (Des) isotherms (SRE: Stabilized Rammed Earth, 433 samples from Hall and Allinson, 2009 [41])

\subsection{Moisture Buffering Value Test}

Figure 6, shows the results of the moisture buffering test. Data points are the average of the results of three samples. The error bar is a simple representation of the standard deviation within the results of the three samples. The results are compared with unstabilised earth (St Antoine) used for a rammed earth building and the SRE sample from Allinson et Hall [42]. The lateritic sample has a very high adsorption compared to the earth samples. 


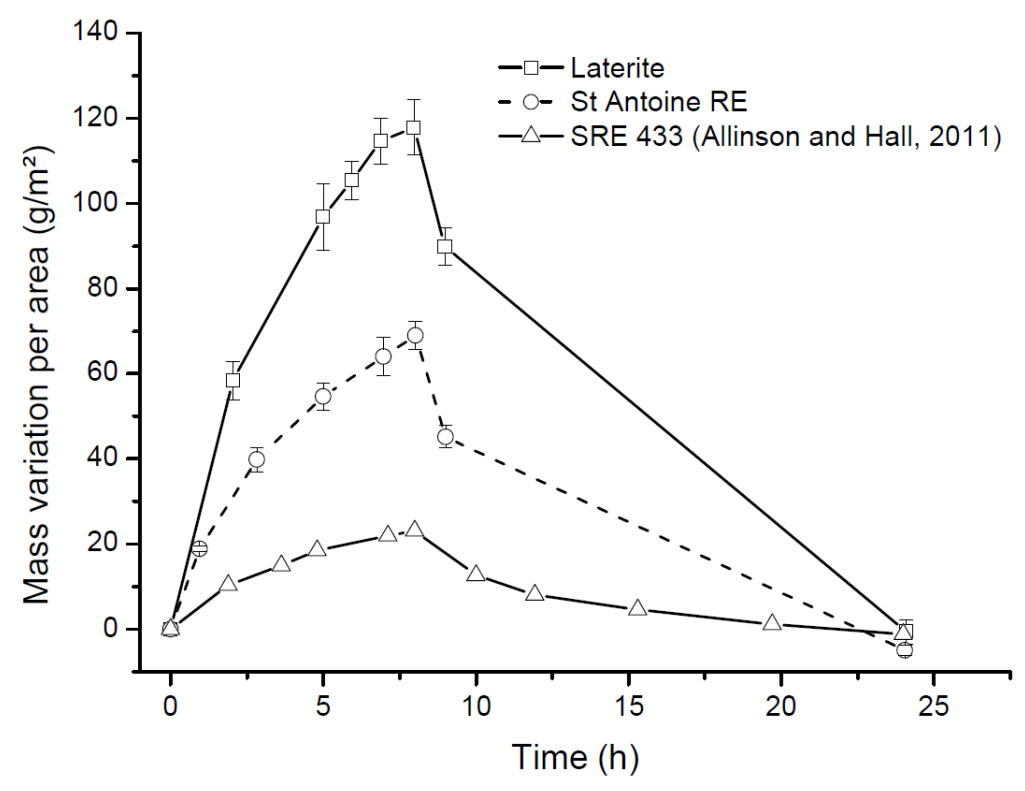

Figure 6: Moisture buffering test

From the experimental curve the $\mathrm{MBV}_{\text {practical }}$ can be calculated according to equation 1 . From the data of the three samples the maximum value after 8h of adsorption varies between 111 and 124 $\mathrm{g} / \mathrm{m}^{2}$. Therefore the MBV varies between 2.65 and $2.95 \mathrm{~g} /\left(\mathrm{m}^{2} . \% \mathrm{RH}\right)$. In the classification proposed in [37] the lateritic building stones would therefore classify as excellent buffering materials.

\section{Mechanical characterization}

\subsection{Three point bending test}

As briefed earlier, in the flexural testing, beam deflection is measured by the LVDT positioned right below the load point. Point load is measured in Newton [N], and the deflection is measured in $\mathrm{mm}$. From theory of bending, the equations to calculate flexural stress in MPa and Strain are given below. 


$$
\begin{array}{rlrl}
\sigma_{x x} & =\frac{3 P L}{2 b d^{2}} & & \text { Equation } 2 . \\
\varepsilon_{x x}=\frac{6 d \delta}{L^{2}} & & \text { Equation } 3 .
\end{array}
$$

With $\sigma_{\mathrm{xx}}$ : the flexural stress or modulus of rupture in [MPa], P : point load in [N], L : length of the beam span (in mm), b : breadth of the beam (in mm), d: depth of the beam (in mm), $\varepsilon_{\mathrm{xx}}$ : longitudinal strain (in $\mathrm{mm} / \mathrm{mm}$ ), $\delta$ : deflection of the beam under point load (in $\mathrm{mm}$ ).

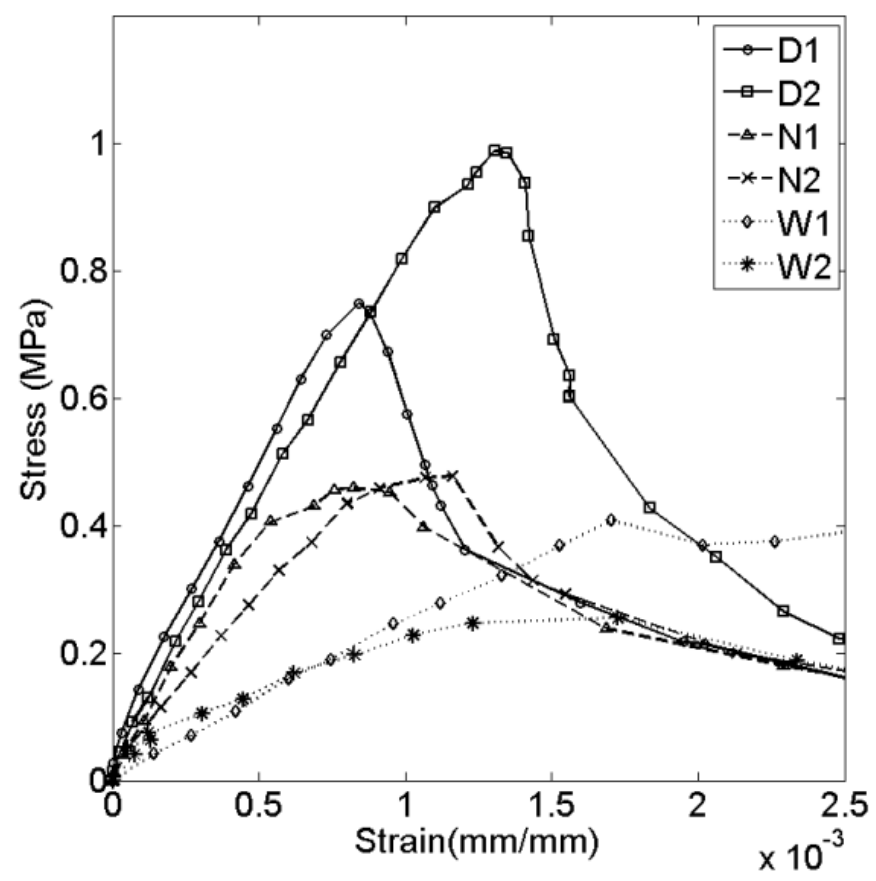

Figure 7: Flexural stress- strain of lateritic specimens

From the load and deflection data obtained during the test, the flexural stress-strain characteristics of the lateritic stone beams in 3 points bending test is plotted as shown in Figure 7. ' $N$ ' representing series exposed to ambient atmosphere with internal moisture of $2 \%$, ' $D$ ' representing series with dry state specimens and ' $\mathrm{W}$ ' representing specimen with average moisture content of $4 \%$ during the test. As predictable, specimen with low moisture content exhibits higher flexural strength characteristics. The average flexural strength of the lateritic specimens at ambient condition is found to be $0.49 \mathrm{MPa}$. There is a tendency of decrease in flexural strength of the material with increase in moisture content as shown in Figure 8. The 
average flexural strength of the lateritic specimen at $4 \%$ moisture content is $40 \%$ of the dry state flexural strength. The average flexural modulus of the laterite in ambient condition is calculated to be $650 \mathrm{MPa}$; the flexural modulus of the material is calculated by plotting the best fit linear secant tangent up to rupture of the material. Results of flexural properties of laterite stone beam are presented in Table 2 .

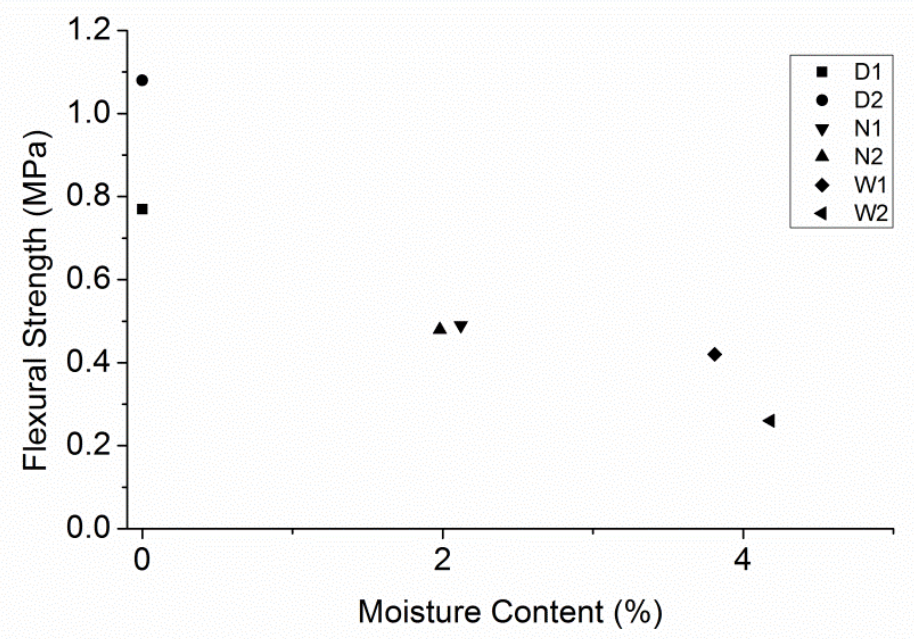

Figure 8 : Variation of Flexural Strength with change in Moisture at test 
Table 2 - Flexural Property of Laterite Stone Beam

\begin{tabular}{|c|c|c|c|c|c|c|}
\hline$\frac{\text { Flexural }}{\underline{\text { test }}}$ & Storage & $\begin{array}{c}\text { Water } \\
\text { Content } \\
{[\%]}\end{array}$ & $\begin{array}{l}\text { Loading } \\
\text { rate } \\
{[\mu \mathrm{m} / \mathrm{s}]}\end{array}$ & $\begin{array}{c}\text { Max } \\
\text { Load } \\
{[\mathrm{N}]}\end{array}$ & $\begin{array}{c}\text { Flexural } \\
\text { Strength, } \\
\mathrm{MPa}\end{array}$ & $\begin{array}{c}\text { Flexural } \\
\text { Modulus, } \\
\text { MPa }\end{array}$ \\
\hline D1 & & 0 & & 573.5 & 0.77 & 880 \\
\hline D2 & $100^{\circ} \mathrm{C}$ & 0 & $5 \mu \mathrm{m} / \mathrm{s}$ & 750 & 1.08 & 780 \\
\hline average & - & - & - & - & 0.93 & 830 \\
\hline N1 & $25^{\circ} \mathrm{C}$ & $2.1 \%$ & $5 \mathrm{um} / \mathrm{s}$ & 333 & 0.49 & 800 \\
\hline $\mathrm{N} 2$ & $50 \%$ RH & $2.0 \%$ & קוח & 362 & 0.48 & 510 \\
\hline average & - & $2.0 \%$ & - & - & 0.49 & 650 \\
\hline W1 & & $3.8 \%$ & & 310 & 0.47 & 230 \\
\hline $\mathrm{W} 2$ & $25^{\circ} \mathrm{C}$ & $4.2 \%$ & $5 \mu \mathrm{m} / \mathrm{s}$ & 189 & 0.26 & 190 \\
\hline average & - & $4.0 \%$ & - & - & 0.37 & 210 \\
\hline
\end{tabular}

\subsection{Compressive Strength}

The compressive stress strain characteristics of the laterite specimen tested in unconfined compression test are shown in Figure 9. The compression test was carried out on 6 specimens, 2 specimens each in 'N', 'D' \& 'W' series. The average compressive strength of the laterite stone specimen exposed to ambient environment is found to be $2.4 \mathrm{MPa}$, and its secant modulus at peak is 2470MPa. The summary of compressive test results is given in Table 3. Similar to earthen construction materials, compressive strength of the laterite stone decreases with increase in moisture content as shown in Figure 10. The average compressive strength of the laterite stone specimen with $4 \%$ moisture content is found to be $55 \%$ of its dry compressive strength. 


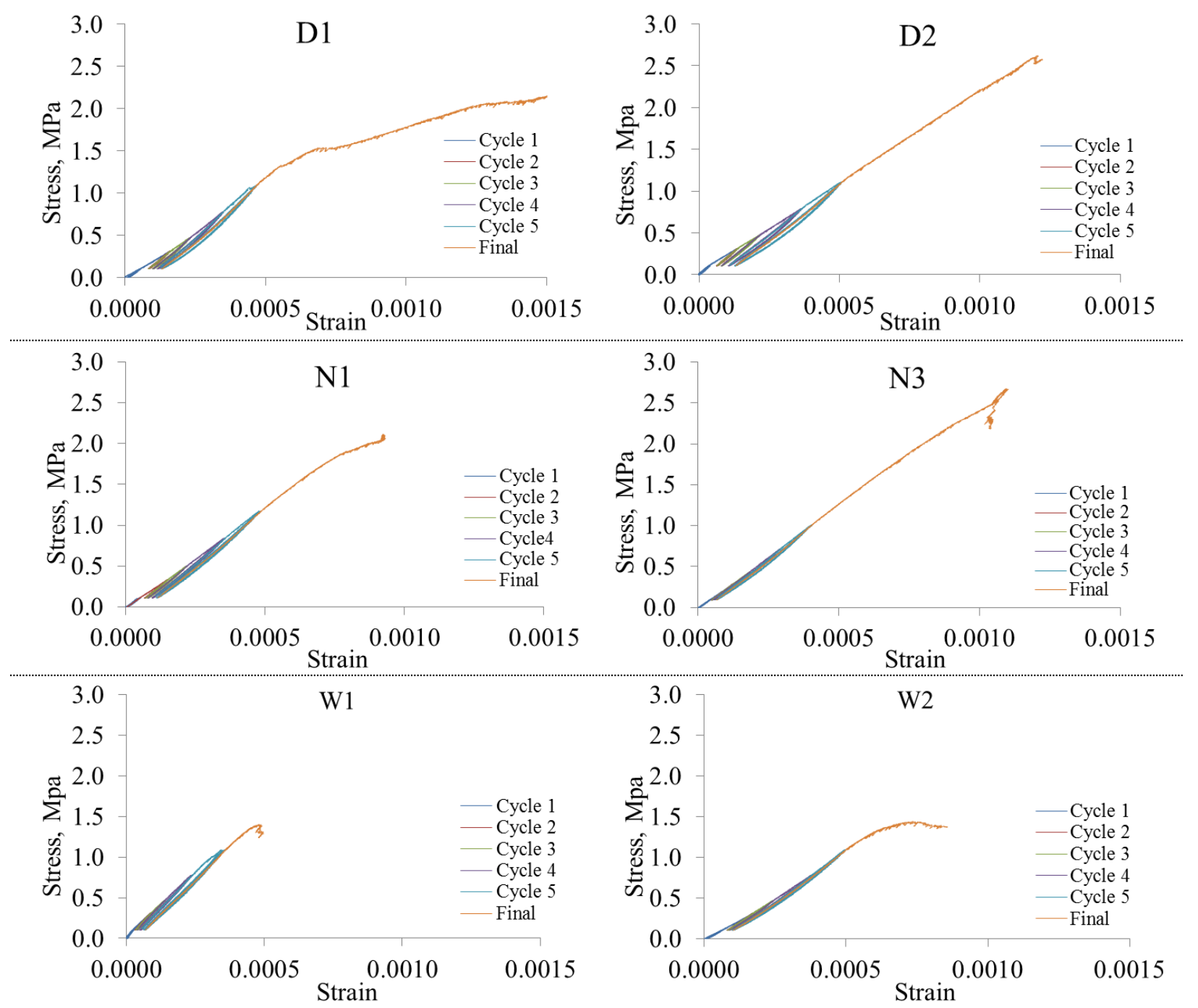

Figure 9- Stress-Strain Graph of Compression Test

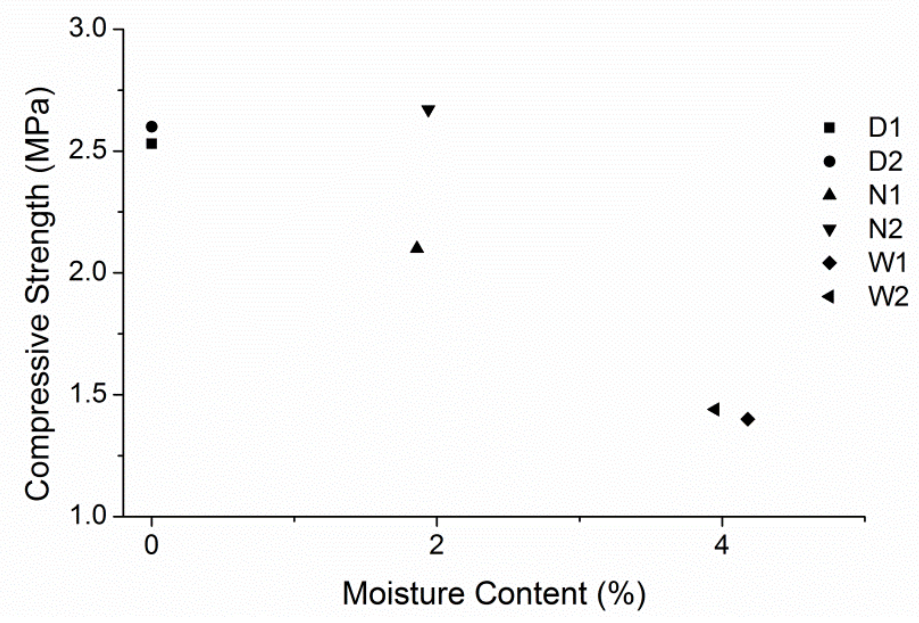

Figure 10: Variation of Compressive Strength with Moisture 
Table 3- Results of Compression Test

\begin{tabular}{|c|c|c|c|c|}
\hline $\begin{array}{c}\text { Compression } \\
\text { Test }\end{array}$ & Storage & $\begin{array}{c}\text { Water } \\
\text { Content }\end{array}$ & $\begin{array}{c}\text { Compressive } \\
\text { Strength, } \\
\mathrm{MPa}\end{array}$ & $\begin{array}{c}\text { Secant } \\
\text { Modulus } \\
\text { (Peak), MPa }\end{array}$ \\
\hline $\begin{array}{l}\text { D1 } \\
\text { D2 }\end{array}$ & $100^{\circ} \mathrm{C}$ & 0 & $\begin{array}{l}2.5 \\
2.6\end{array}$ & $\begin{array}{l}2220 \\
2150\end{array}$ \\
\hline average & - & 0 & 2.6 & 2190 \\
\hline N1 & $\begin{array}{c}25^{\circ} \mathrm{C} \\
\&\end{array}$ & $1.9 \%$ & 2.1 & 2460 \\
\hline $\mathrm{N} 2$ & $50 \% \mathrm{RH}$ & $1.9 \%$ & 2.7 & 2490 \\
\hline average & - & $1.9 \%$ & 2.4 & 2470 \\
\hline W1 & $25^{\circ} \mathrm{C}$ & $4.2 \%$ & 1.4 & 2970 \\
\hline W2 & & $4.0 \%$ & 1.4 & 2160 \\
\hline average & - & $4.1 \%$ & 1.4 & 2560 \\
\hline
\end{tabular}

\subsection{Young's modulus}

Cyclic loading is very helpful in understanding the elastic behaviour of the material, in this analysis to calculate the elastic modulus (secant), best fit linear line is drawn to each cycles (including 3 repetitions) as shown in Figure 11, where all the cycles are shown. The secant modulus of the first cycle is called as the initial secant modulus, which is low compared to cycles (2-5), this may be attributed to the closer of micro cracks in the material. Figure 12 shows the secant modulus of samples at various stages during loading. The variation of the secant modulus between cycles $2-5$ is less and exhibits linearity. The average cyclic (2-5) secant modulus of dry (D) and ambient $(\mathrm{N})$ condition varies in between 2600MPa to 2800MPa (Figure 13). In Figure 13, initial secant modulus, average of secant modulus of cycles 2, 3, 4 and 5 and secant modulus at peak are plotted against the variation of moisture. The behaviour of moist samples doesn't provide convincing information. The variation between initial secant modulus and secant 
modulus at peak is seen to be negligible (less than 10\%) for dry and ambient condition; this may suggest secant modulus at peak can be considered for analysis (given in Table 3). It should also be noted that the secant modulus at dry and ambient condition doesn't vary much, so the assumption of linear behaviour seems to be correct for this kind of material, if water content remains limited.
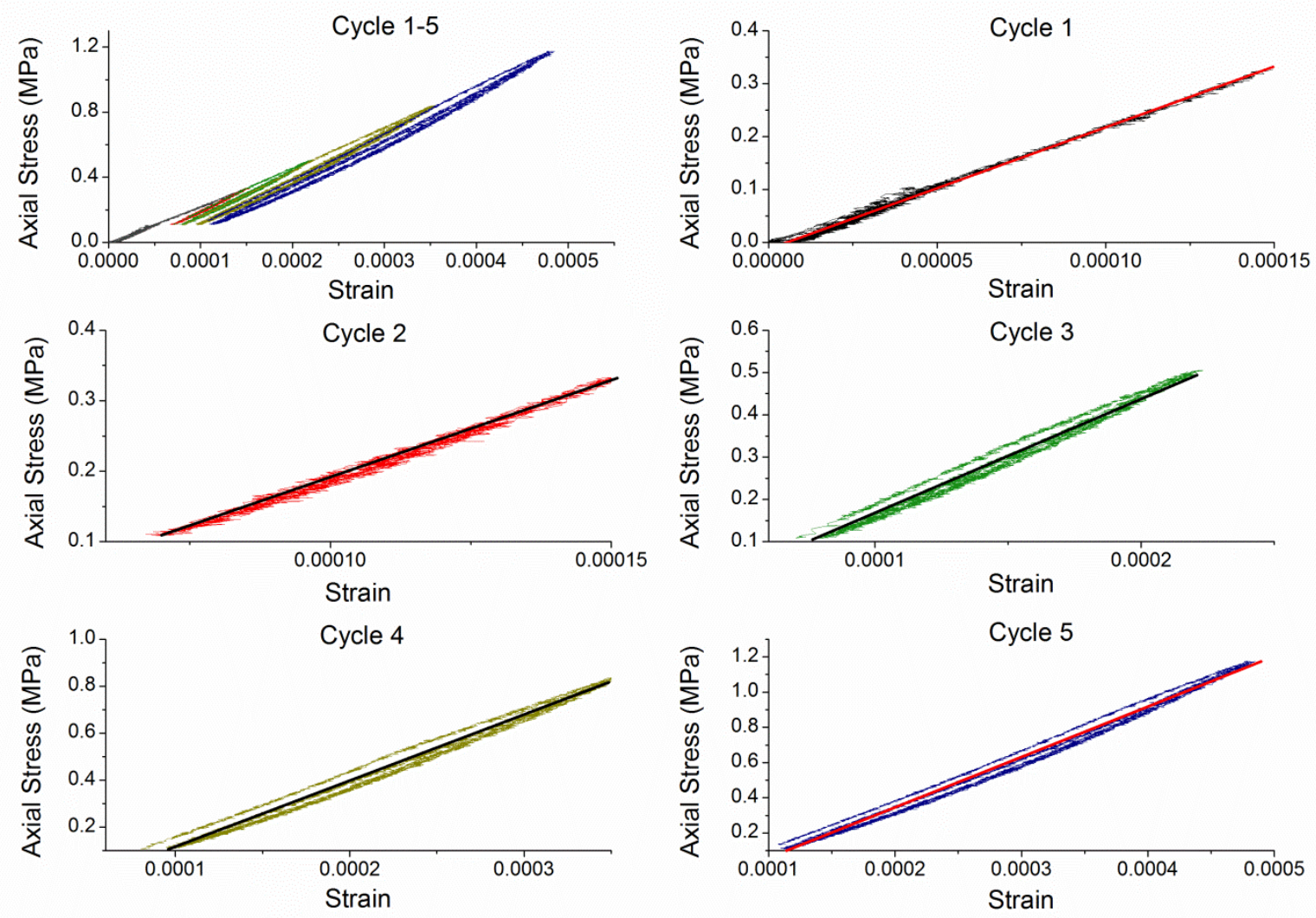

Figure 11 : An Example of Linear Elastic behaviour of Laterite Stone Specimen 


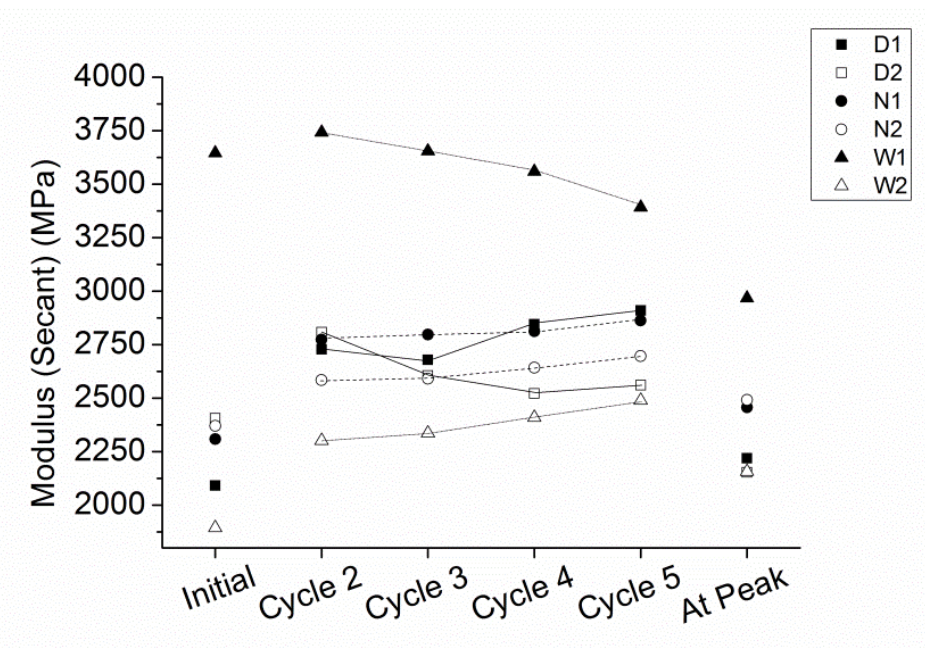

Figure 12: Variation of Modulus at each cycle

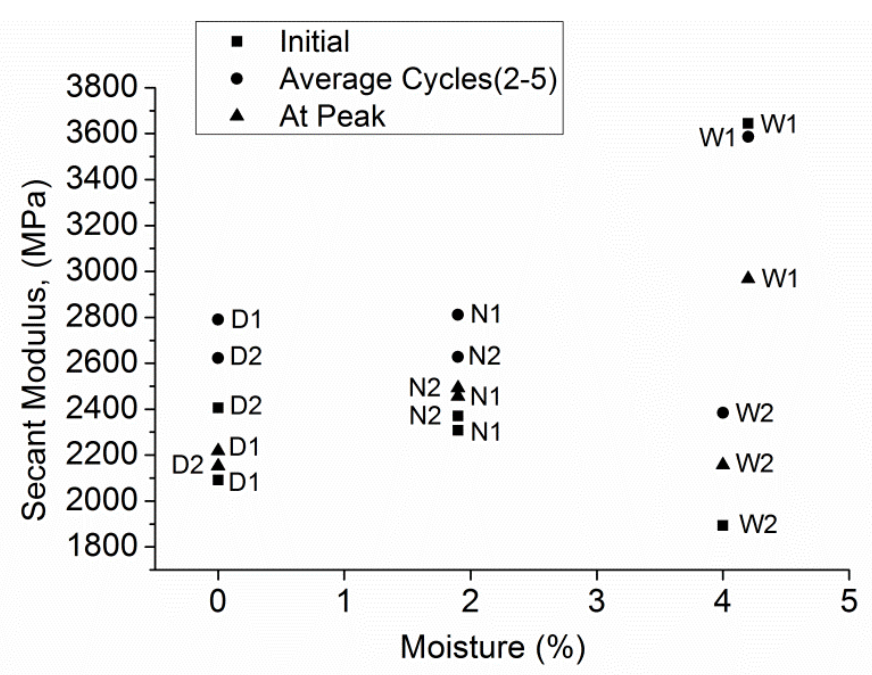

Figure 13: Change of secant modulus and average cyclic modulus with change in moisture

\subsection{Irreversible strain}

From cyclic loading it was observed that the material exhibits residual strain after reaching $1.08 \mathrm{kN}$ load (cycle2). In the first cycle, material completely regains its straining showing perfect elasticity. From second cycle, when material is loaded to $1.08 \mathrm{kN}$ and above, material does not regain its original shape upon unloading exhibiting irreversible straining. Though LBS exhibits hysteric loop during unloading and reloading, from Figure 11, it can be said the hysteric loop created is very small and negligible. The cyclic unloading and reloading is nearly linear, and for 
simplifying the analysis in this study linear variation is considered. To calculating elastic strain $\left(\varepsilon_{\mathrm{e}}\right)$ recovery and irreversible strain $\left(\varepsilon_{\mathrm{ir}}\right)$, the last known strain upon unloading of each cycle is linearly extended on to the $\mathrm{x}$-axis as shown in Figure 14. The point of intersection on the $\mathrm{x}$-axis is considered as the irreversible strain material has undergone for that respective cycle. The maximum strain material has undergone for each cycle at its maximum stress is taken as $\varepsilon_{t}$. The ratio of irreversible strain $\left(\varepsilon_{\mathrm{ir}}\right)$ to total strain $\left(\varepsilon_{\mathrm{t}}\right)$ of each cycle is taken as the percentage of irreversible strain material has undergone for a cycle. The percentage of irreversible strain LBS specimens has undergone is shown in Figure 15. Specimens D1 \& W2 has wide spread of irreversible strain, it was observed these specimens have prolonged straining before failure, whereas the other specimen showed brittle failure nature. Though it is difficult to quantify the plasticity of the material, in general it can be said that material shows less than $20 \%$ of irreversible strain property. This information adds value to the assumption of linear behaviour. The maximum stress and strain values of the laterite test specimens are given in Table 4.

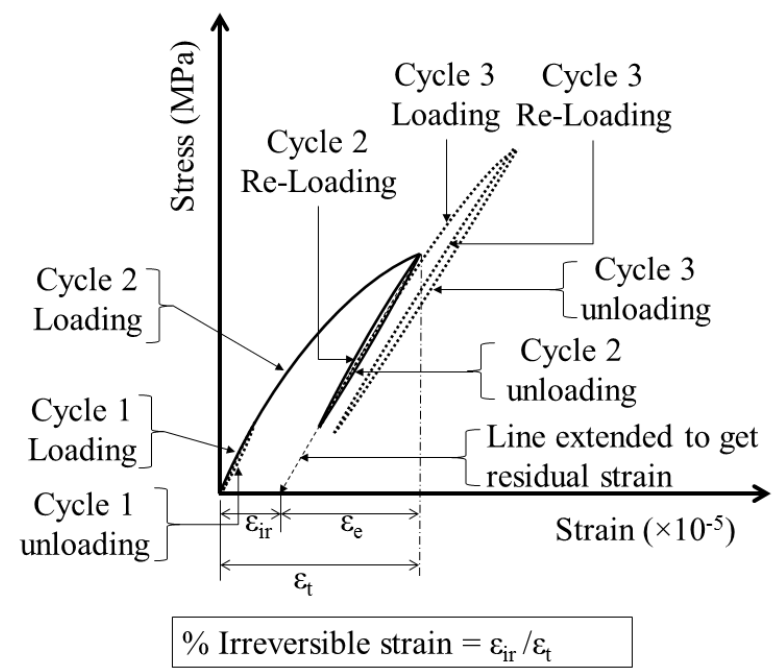

Figure 14: Graphical explanation for calculation of irreversible strain 


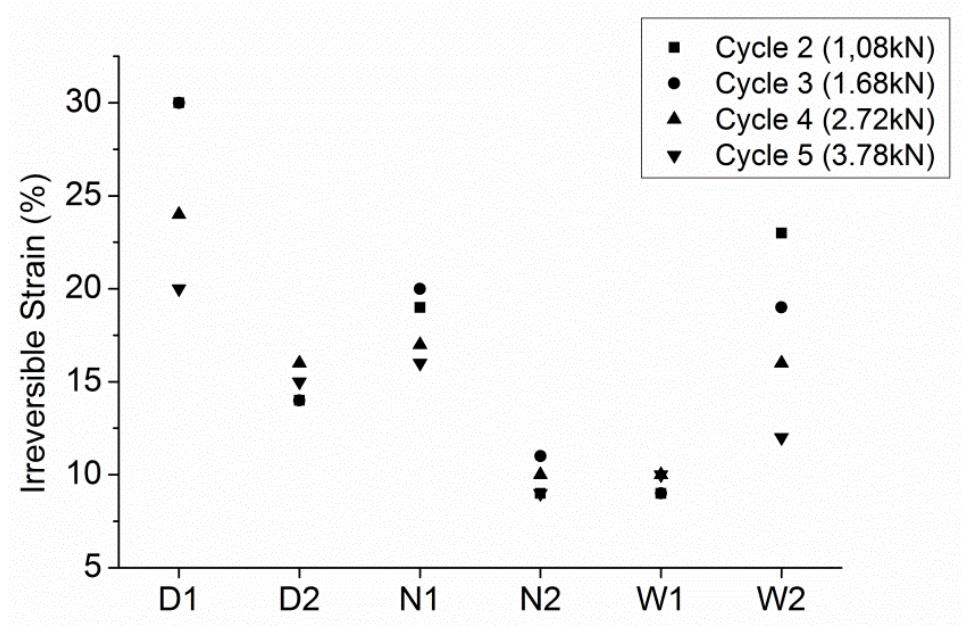

Figure 15: Percentage of Irreversible strain with respect to cycles (load)

Table 4: Failure Stress - Strain

\begin{tabular}{|c|c|c|c|}
\hline $\begin{array}{c}\text { Laterite } \\
\text { Specimen }\end{array}$ & $\begin{array}{c}\text { Moisture } \\
{[\%]}\end{array}$ & $\begin{array}{c}\text { stress at } \\
\text { failure } \\
\sigma(\max ), \\
\mathrm{MPa}\end{array}$ & $\begin{array}{c}\text { Strain at } \\
\text { failure } \\
\varepsilon, \\
{\left[10^{\wedge}-5\right]}\end{array}$ \\
\hline \hline $\mathrm{D} 1$ & 0 & 2.5 & 160 \\
$\mathrm{D} 2$ & 0 & 2.6 & 120 \\
\hline $\mathrm{N} 1$ & 1.9 & 2.1 & 90 \\
$\mathrm{~N} 2$ & 1.9 & 2.7 & 110 \\
$\mathrm{~W} 1$ & 4.2 & 1.4 & 50 \\
$\mathrm{~W} 2$ & 4.0 & 1.4 & 90 \\
\hline
\end{tabular}

\section{Discussion}

The first remarks can be made on the highly hygroscopic characteristics of the material. Sorption isotherms exhibit a strong hysteresis and between 20 to $40 \mathrm{~kg} / \mathrm{m}^{3}$ water content in the middle range of relative humidities. In this study the laterite samples compared with rammed earth samples present higher hygroscopic water adsorption characteristics. The moisture buffering results show the same trend with a dynamic adsorption at least twice the values of the rammed earth samples and comparable to those obtained for unfired clay bricks [43]. 
The corresponding calculated MBV is $2.8 \mathrm{~g} / \mathrm{m}^{2} . \% \mathrm{RH}$ for $75 \% / 33 \% \mathrm{RH}$ cycles. MBVs over 2 $\mathrm{g} / \mathrm{m}^{2} . \% \mathrm{RH}$ are considered as excellent moisture buffering materials. From these results it can be concluded that the material can have a positive impact on indoor air quality. Any exposed surface will act as a passive climate regulator. This potential has previously been described for other building materials [44]. It can however be discussed if such behaviour would also be effective in tropical climates where Laterite stones can usually be found. A study using simulation tools to access the influence of the building envelope on the interior climate in tropical climate conditions shows that the addition of hygroscopic materials lowers the interior RH peaks [45].

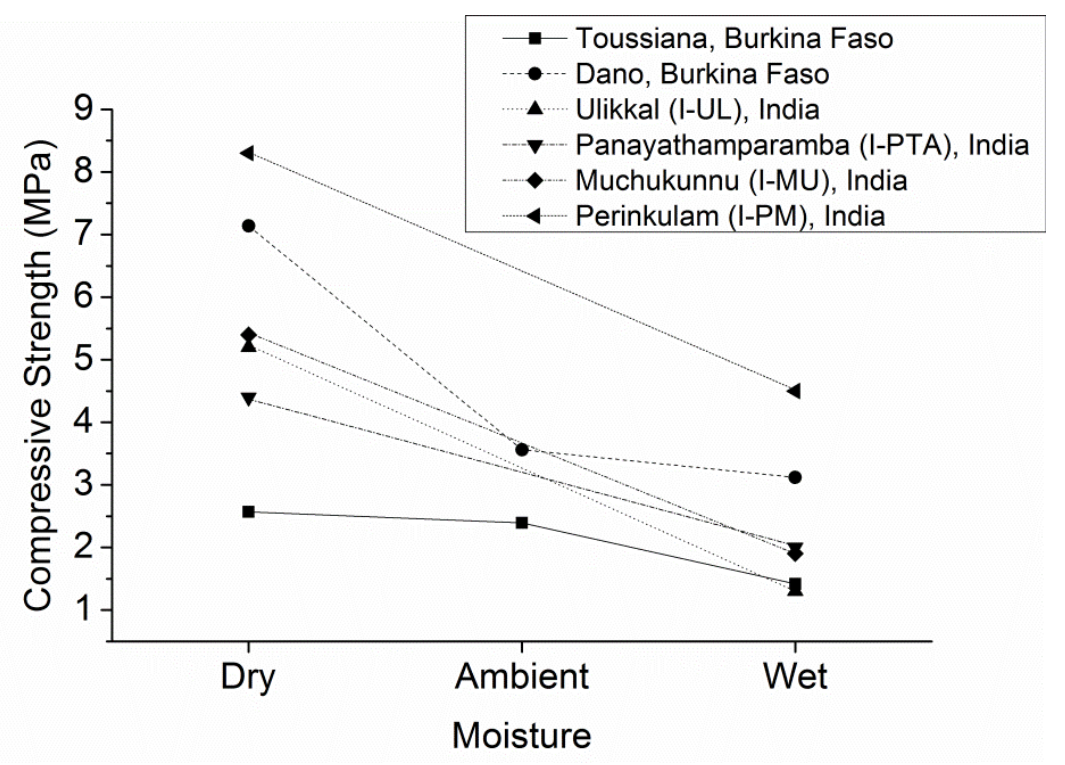

\section{Figure 16: Variation of compressive strength of Laterite (different quarries) with moisture}

Compressive strength of porous material varies with change in moisture condition. Experimental results show that, the compressive strength of LBS reduces with increase in the moisture content. In Figure 16, the compressive strength at different moisture state of laterite blocks from Dano, Burkina Faso [24] and Malabar region, India [22] are presented along with the LBS (Toussiana) experimental results obtained from this study. Ulikkal (I-UL), Panayathamparamba (I-PTA), Muchukunnu (I-MU) and Perinkulam (I-PM) are different quarries of laterite blocks in Malabar region, India [22,26]. Wet compressive strength of laterite blocks from Malabar region in between $25 \%-54 \%$ of its dry compressive strength, the variation in compressive strength depends on the quarry and composition of rock [46]. The dry, ambient and saturated compressive strength of laterite blocks from Dano, Burkina Faso [24] are shown in 
Figure 16, it has to be noted that, the aspect ratio [28] of the test specimens in this case were less than 2, hence compressive strength of laterite blocks from Dano, Burkina Faso might require coefficient of correction. The ambient compressive strength of laterite block (Dano) is $50 \%$ of its dry state, whereas the tested material from Toussiana losses only $7 \%$ of its dry compressive strength at ambient condition. In both cases, moisture at ambient condition is around $2 \%$. Wet compressive strength of laterite blocks (Dano) is $45 \%$ of its dry compressive strength. In general, it can be said that the wet or saturated compressive strength of laterite stones is $40 \%-50 \%$ of its dry compressive strength.

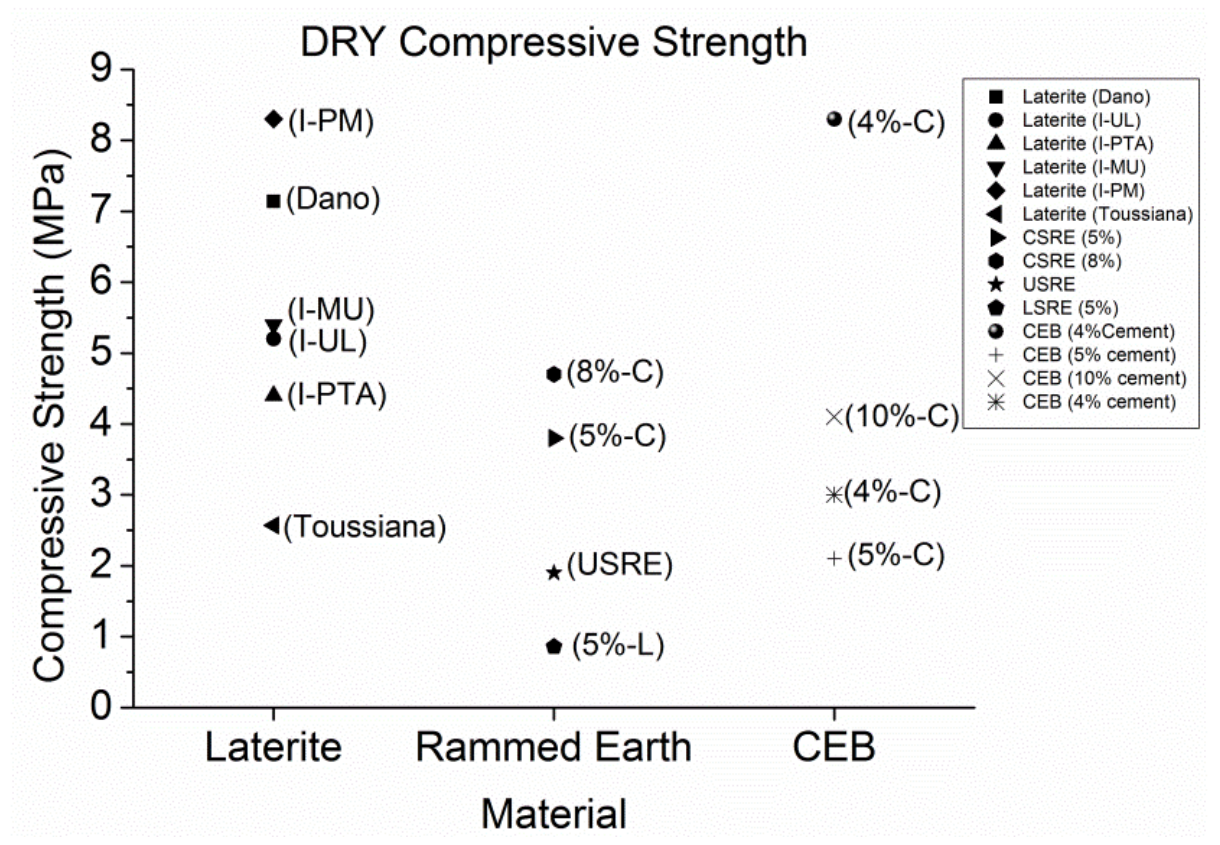

Figure 17: Comparison of compressive strength of Laterite, Rammed earth, CEB at dry state.

Compressive strength of a building material is one of the decisive factors in recommending its suitability as an alternative construction material. In this analysis for comparison, stabilised compressed earth block (CEB) [7,28,47,48], cement stabilised rammed earth (CSRE) [49], lime stabilised rammed earth (LSRE)[15], and unstabilised rammed earth (USRE) [29] are considered. The dry and wet compressive strength of the materials are considered and plotted as shown in Figure $17 \&$ Figure 18. The dry compressive strength of the rammed earth varies between $1-5 \mathrm{MPa}$, the compressive strength of the USRE being the lowest, with increase in the percentage of cement and lime content there is increase in strength. Similarly 
compressive strength of stabilized $\mathrm{CEB}$ varies between 2-8MPa, depending upon the percentage of cement and clay in the soil[47]. In the case of laterite, dry compressive strength varies from 2.5-8.3MPa depending on the quarry and its chemical and mineral composition, the material tested in this study exhibits $2.6 \mathrm{MPa}$ as the average dry compressive strength.

In general wet compressive strength of stabilised rammed earth and stabilised CEB losses $50 \%$ of its dry compressive strength, similar to the case of LBS. As shown in Figure 18, wet compressive strength of rammed earth is in between of $0.5-2.3 \mathrm{MPa}$, and that of CEB is in between 1.2-3.2MPa. It is interesting to see that the wet compressive strength of laterite also varies in the range of $1.4-3.2 \mathrm{MPa}$, the material tested in this study has an average wet compressive strength of $1.4 \mathrm{MPa}$.

This shows that the dry \& wet compressive strength of LBS is similar to stabilized earth materials. According to [19] the induration process of laterite soils involves the crystallisation of iron oxide minerals cementing the aggregates over a more or less long period of time. A further physico-chemical study of the nature of this induration may allow its comparison and potentially replicate the process to the stabilisation of earth materials. Compared to the stabilisation of earth materials the natural induration of laterite soils has no environmental impact yet the use of laterite stones involves extraction and transport from the quarry to the building site and therefore increasing its environmental impact compared to unfired earth. It is interesting to note that the mechanical characteristic of laterite varies with quarry, region, and nature of deposits. The variation of strength with quarries might be attributed to change in the chemical and mineral composition during induration process. To understand how laterite stone gains its strength, a detail mineral and chemical analysis has to be carried out. 


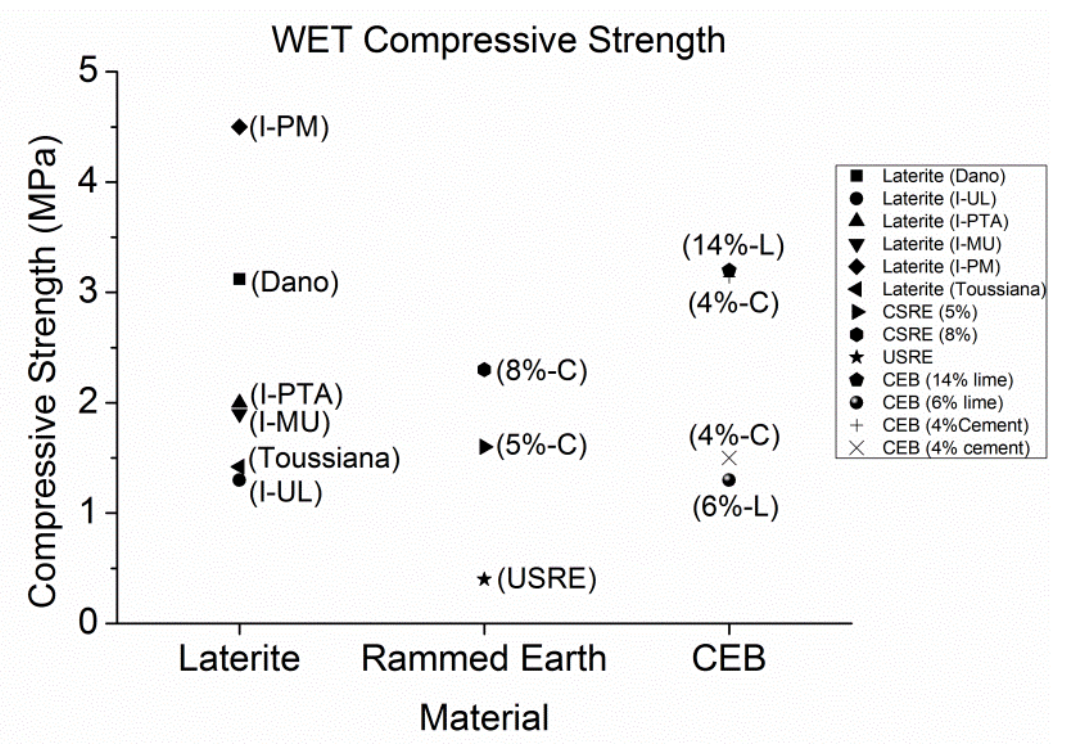

\section{Figure 18: Comparison of compressive strength of Laterite, Rammed earth, \& CEB at saturated / wet state.}

\section{Conclusion}

In this study, LBS from Toussiana, Burkina Faso is studied for its hygroscopic and mechanical parameters. From sorption isotherm hysteresis and dynamic adsorption tests, laterite exhibits strong hygroscopic characteristics with MBV of $2.8 \mathrm{~g} /\left(\mathrm{m}^{2} . \% \mathrm{R} . \mathrm{H}\right)$, which is better than the SRE \& USRE. It was also observed that the flexural strength and compressive strength of the LBS decreases with increase in moisture content, the flexural and compressive strength of the LBS at ambient conditions was found to be $0.55 \mathrm{MPa}$ and $2.4 \mathrm{MPa}$ respectively. Though the strength decreasing tendency is found with moisture, there is need for more experimental investigation to propose correlation of strength with moisture variation. The average secant modulus of the specimens at ambient condition was found to be 2470MPa from cyclic loading, with irreversible strain of $20 \%$. It was also seen that that the mechanical properties of LBS varies with quarry and region, hence it is highly recommended to study mechanical properties of laterite from each quarry. Further studies on chemical and mineral analysis of laterite would provide comprehensive analysis of LBS. The dry and wet compressive strength of laterite is on par with the stabilised earth construction materials, yet it exhibits a strong buffering capacity. In the light of this research laterite stone block as an eco-friendly and low cost building material seems to be a valid alternative solution. Furthermore, the natural induration that occurs during its formation could 
prove through further investigation to be a stabilisation solution for earth materials. This could widen the research on eco-friendly soil stabilisers used for stabilising earthen building materials.

\section{Acknowledgment}

The first author would like to thank CEFIPRA for providing financial support and Ecole Nationale des Travaux Publics de l'Etat (ENTPE), Vaulx en Velin, France for supporting the study. The authors would also thank Mr. Stephane Cointet for providing technical aid in the laboratory of ENTPE. 


\section{Reference}

[1] B. V. Venkatarama Reddy, K.S. Jagadish, Embodied energy of common and alternative building materials and technologies, Energy Build. 35 (2003) 129-137.

doi:10.1016/S0378-7788(01)00141-4.

[2] R. Spence, H. Mulligan, Sustainable development and the construction industry, Habitat Int. 19 (1995) 279-292. doi:10.1016/0197-3975(94)00071-9.

[3] B. V. Venkatarama Reddy, Sustainable building technologies, Curr. Sci. 87 (2004) 899907.

[4] J.-C. Morel, A. Mesbah, M. Oggero, P. Walker, Building houses with local materials: means to drastically reduce the environmental impact of construction, Build. Environ. 36 (2001) 1119-1126.

[5] Y. Millogo, M. Hajjaji, R. Ouedraogo, Microstructure and physical properties of limeclayey adobe bricks, Constr. Build. Mater. 22 (2008) 2386-2392. doi:10.1016/j.conbuildmat.2007.09.002.

[6] Y. Millogo, M. Hajjaji, J.-C. Morel, Physical properties, microstructure and mineralogy of termite mound material considered as construction materials, Appl. Clay Sci. 52 (2011) 160-164. doi:10.1016/j.clay.2011.02.016.

[7] P. Walker, T. Stace, Properties of some cement stabilised compressed earth blocks and mortars, Mater. Struct. Constr. 30 (1997) 545-551. doi:10.1007/BF02486398.

[8] J.E. Oti, J.M. Kinuthia, J. Bai, Engineering properties of unfired clay masonry bricks, Eng. Geol. 107 (2009) 130-139. doi:10.1016/j.enggeo.2009.05.002.

[9] L. Soudani, A. Fabbri, J. Morel, M. Woloszyn, A. Grillet, A coupled hygrothermal model for earthen materials, Energy Build. (2015).

[10] F. McGregor, A. Heath, D. Maskell, A. Fabbri, J.-C. Morel, D. Maskel, et al., A review on the buffering capacity of earth building materials, Proc. Inst. Civ. Eng. - Constr. Mater. 0 (2016) 1-11. doi:10.1680/jcoma.15.00035.

[11] P. Maillard, J.E. Aubert, Effects of the anisotropy of extruded earth bricks on their hygrothermal properties, Constr. Build. Mater. 63 (2014) 56-61. doi:10.1016/j.conbuildmat.2014.04.001.

[12] H. Cagnon, J.E. Aubert, M. Coutand, C. Magniont, Hygrothermal properties of earth bricks, Energy Build. 80 (2014) 208-217. doi:10.1016/j.enbuild.2014.05.024.

[13] F. Champiré, A. Fabbri, J. Morel, H. Wong, F. McGregor, Impact of relative humidity on the mechanical behavior of compacted earth as a building material, Constr. Build. Mater. (n.d.).

[14] B.V. Venkatarama Reddy, P. Prasanna Kumar, Structural Behavior of Story-High Cement Stabilized Rammed-Earth Walls under Compression, J. Mater. Civ. Eng. 23 (2011) 240247. doi:10.1061/(ASCE)MT.1943-5533.0000155.

[15] D. Ciancio, C.T.S. Beckett, J.A.H. Carraro, Optimum lime content identification for limestabilised rammed earth, Constr. Build. Mater. 53 (2014) 59-65. doi:10.1016/j.conbuildmat.2013.11.077. 
[16] D. Maskell, A. Heath, P. Walker, Comparing the Environmental Impact of Stabilisers for Unfired Earth Construction, Key Eng. Mater. 600 (2014) 132-143. doi:10.2966/scrip.

[17] B.V. Venkatarama Reddy, M.S. Latha, Retrieving clay minerals from stabilised soil compacts, Appl. Clay Sci. 101 (2014) 362-368. doi:10.1016/j.clay.2014.08.027.

[18] J.C. Morel, J.E. Aubert, Y. Millogo, E. Hamard, a. Fabbri, Some observations about the paper "Earth construction: Lessons from the past for future eco-efficient construction" by F. Pacheco-Torgal and S. Jalali, Constr. Build. Mater. 44 (2013) 419-421. doi:10.1016/j.conbuildmat.2013.02.054.

[19] R. Maignien, Review of research on laterites, Nat. Resour. Res. IV (1966) 1-136.

[20] M. D. Gidigasu, Laterite Soil Engineering, Pedogenesis and Engineering Principles, Elsevier Scientific Publishing Company, 1976.

[21] Y. Tardy, B. Kobilsek, H. Paquet, Mineralogical composition and geographical distribution of african and brazilian periatlantic laterites. The influence of continental drift and tropical paleoclimates during the past 150 million years and implications for India and Australia, J. African Earth Sci. 12 (1991) 283-295. doi:10.1017/CBO9781107415324.004.

[22] A.K. Kasthurba, K. Reddy R, V. Reddy D, Use of Laterite as a Sustainable Building Material in Developing Countries, Int. J. Earth Sci. Eng. 07 (2015) 1251-1258.

[23] A. Lawane, R. Vinai, A. Pantet, J. Thomassin, Characterisation of laterite stone as building material in Burkina Faso : state of the art of the on-going research and its perspectives, in: Journées Sci. Du 2iE, ouagadougou, 2011: pp. 2-5.

[24] A. Lawane, A. Pantet, R. Vinai, J. Hugues, Etude géologique et géomécanique des latérites de Dano ( Burkina Faso ) pour une utilisation dans 1' habitat, in: XXIXe Recontres Univ. Genie Civ., 2011: pp. 206-215.

[25] S. Unnikrishnan, M.C. Narasimhan, K. Venkataramana, Uniaxial Compressive Strength of Laterite Masonry Prisms - An Evaluation, in: Int. Conf. Earth Sci. Eng. - 2010, International Journal of Earth Science and Engineering, 2010: pp. 115-128.

[26] A.K. Kasthurba, M. Santhanam, H. Achyuthan, Investigation of laterite stones for building purpose from Malabar region, Kerala, SW India - Part 1: Field Studies and Profile Characterisation, Constr. Build. Mater. 21 (2007) 73-82. doi:10.1016/j.conbuildmat.2006.12.003.

[27] A.S. Muntohar, Engineering characteristics of the compressed-stabilized earth brick, Constr. Build. Mater. 25 (2011) 4215-4220. doi:10.1016/j.conbuildmat.2011.04.061.

[28] J.-C. Morel, A. Pkla, P. Walker, Compressive strength testing of compressed earth blocks, Constr. Build. Mater. 21 (2007) 303-309.

[29] Q. Bui, J. Morel, S. Hans, P. Walker, Effect of moisture content on the mechanical characteristics of rammed earth, Constr. Build. Mater. 54 (2014) 163-169.

[30] T.-T. Bui, Q.-B. Bui, a. Limam, S. Maximilien, Failure of rammed earth walls: From observations to quantifications, Constr. Build. Mater. 51 (2014) 295-302. doi:10.1016/j.conbuildmat.2013.10.053.

[31] M. Hall, Y. Djerbib, Rammed earth sample production: context, recommendations and consistency, Constr. Build. Mater. 18 (2004) 281-286. 
doi:10.1016/j.conbuildmat.2003.11.001.

[32] V. Maniatidis, P. Walker, Structural capacity of rammed earth in compression, J. Mater. Civ. Eng. (2008) 230-239. http://ascelibrary.org/doi/abs/10.1061/(ASCE)08991561(2008)20:3(230) (accessed March 29, 2013).

[33] E. Adorni, E. Coïsson, D. Ferretti, In situ characterization of archaeological adobe bricks, Constr. Build. Mater. 40 (2013) 1-9. doi:10.1016/j.conbuildmat.2012.11.004.

[34] D. Silveira, H. Varum, A. Costa, Influence of the testing procedures in the mechanical characterization of adobe bricks, Constr. Build. Mater. 40 (2013) 719-728. doi:10.1016/j.conbuildmat.2012.11.058.

[35] J.E. Aubert, A. Marcom, P. Oliva, P. Segui, Chequered earth construction in south-western France, J. Cult. Herit. 16 (2015) 293-298. doi:10.1016/j.culher.2014.07.002.

[36] ISO-24353, Hygrothermal performance of building materials and products-Determination of moisture adsorption/desorption properties in response to humidity variation, (2008) --.

[37] C. Rode, R.H. Peuhkuri, L.H. Mortensen, K.K. Hansen, B. Time, A. Gustavsen, et al., Moisture buffering of building materials, 2005.

[38] J.E. Aubert, a. Fabbri, J.C. Morel, P. Maillard, An earth block with a compressive strength higher than 45MPa!, Constr. Build. Mater. 47 (2013) 366-369. doi:10.1016/j.conbuildmat.2013.05.068.

[39] J.E. Aubert, P. Maillard, J.C. Morel, M. Al Rafii, Towards a simple compressive strength test for earth bricks ? Towards a simple compressive strength test for earth, Mater. Struct. (2015) 1641-1654. doi:10.13140/RG.2.1.4641.4242.

[40] F. Rouquerol, J. Rouquerol, K.S.W. Sing, Adsorption by Powders and Porous Solids: Principles, Methodology and Applications, Academic Press, 1999.

[41] M. Hall, D. Allinson, Assessing the effects of soil grading on the moisture contentdependent thermal conductivity of stabilised rammed earth materials, Appl. Therm. Eng. 29 (2009) 740-747.

[42] D. Allinson, M. Hall, Humidity buffering using stabilised rammed earth materials, Proc. ICE - Constr. Mater. (2012) 1-10. doi:10.1680/coma.11.00023.

[43] F. McGregor, A. Heath, E. Fodde, A. Shea, Conditions affecting the moisture buffering measurement performed on compressed earth blocks, Build. Environ. 75 (2014) 11-18.

[44] T. Padfield, PhD Thesis : The role of absorbent building materials in moderating changes of relative humidity, The Technical University of Denmark, 1998.

[45] H.. Künzel, A. Holm, D. Zirkelbach, A.N. Karagiozis, Simulation of indoor temperature and humidity conditions including hygrothermal interactions with the building envelope, Sol. Energy. 78 (2005) 554-561. doi:10.1016/j.solener.2004.03.002.

[46] A.K. Kasthurba, M. Santhanam, H. Achyuthan, Investigation of laterite stones for building purpose from Malabar region, Kerala, SW India - Chemical analysis and microstructure studies, Constr. Build. Mater. 22 (2008) 2400-2408.

doi:10.1016/j.conbuildmat.2006.12.003.

[47] B.V.V. Reddy, R. Lal, K.N. Rao, Optimum Soil Grading for the Soil-Cement Blocks, J. Mater. Civ. Eng. 19 (2007) 139-148. 
[48] B.V.V. Reddy, S.R. Hubli, Properties of lime stabilised steam-cured blocks for masonry, Mater. Struct. 35 (2002) 293-300. doi:10.1007/BF02482135.

[49] B. V. Venkatarama Reddy, P. Prasanna Kumar, Cement stabilised rammed earth. Part B: compressive strength and stress-strain characteristics, Mater. Struct. 44 (2011) 695-707. doi:10.1617/s11527-010-9659-8. 
List of Figures:

FIGURE 1: LOCATION OF TOUSSIANA IN THE PROVINCE OF HOUET IN BURKINA- FASO

FIGURE 2: X-RAY DIFFRACTION PATTERN OF THE LBS

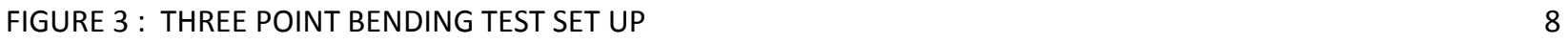

FIGURE 4 COMPRESSION TEST SETUP 9

FIGURE 5 : ADSORPTION (ADS) AND DESORPTION (DES) ISOTHERMS (SRE: STABILIZED RAMMED EARTH, 433 SAMPLES FROM HALL AND ALLINSON, 2009 [41]) 11

FIGURE 6: MOISTURE BUFFERING TEST 12

FIGURE 7: FLEXURAL STRESS- STRAIN OF LATERITIC SPECIMENS

FIGURE 8 : VARIATION OF FLEXURAL STRENGTH WITH CHANGE IN MOISTURE AT TEST 14

FIGURE 9- STRESS-STRAIN GRAPH OF COMPRESSION TEST 16

FIGURE 10: VARIATION OF COMPRESSIVE STRENGTH WITH MOISTURE 16

FIGURE 11 : AN EXAMPLE OF ELASTIC BEHAVIOUR OF LATERITE STONE SPECIMEN 18

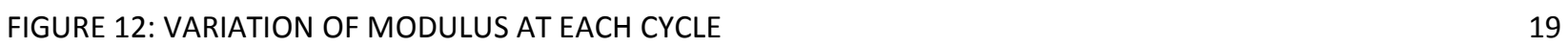

FIGURE 13: CHANGE OF SECANT MODULUS AND AVERAGE CYCLIC MODULUS WITH CHANGE IN MOISTURE 19

FIGURE 14: GRAPHICAL EXPLANATION FOR CALCULATION OF IRREVERSIBLE STRAIN 20

FIGURE 15: PERCENTAGE OF IRREVERSIBLE STRAIN WITH RESPECT TO CYCLES (LOAD) 21

FIGURE 16: VARIATION OF COMPRESSIVE STRENGTH OF LATERITE (DIFFERENT QUARRIES) WITH MOISTURE 22

FIGURE 17: COMPARISON OF COMPRESSIVE STRENGTH OF LATERITE, RAMMED EARTH, CEB AT DRY STATE. 23

FIGURE 18: COMPARISON OF COMPRESSIVE STRENGTH OF LATERITE, RAMMED EARTH, \& CEB AT SATURATED /

WET STATE. 